\title{
PERANCANGAN DAN PEMBUATAN APLIKASI SISTEM GUDANG SENJATA (SGS) DI BATALYON XYZ
}

\author{
Yudho Yudhanto \\ Fakultas MIPA, Program Studi D3 Teknik Informatika \\ Universitas Negeri Sebelas Maret \\ Email: yuda@mipa.uns.ac.id \\ Setiadi Darmawan \\ Fakultas MIPA, Program Studi D3 Teknik Informatika \\ Universitas Negeri Sebelas Maret \\ Email: adiozh@gmail.com \\ Winita Sulandari \\ Fakultas MIPA, Program Studi Statistika \\ Universitas Negeri Sebelas Maret \\ Email:winita@mipa.uns.ac.id
}

\begin{abstract}
ABSTRAK
Gudang senjata merupakan tempat penting dalam sebuah batalyon. Fungsi dari gudang senjata ialah tempat untuk menyimpan senjata seluruh anggota ketika tidak dipakai ketika bertugas. Anggota memperoleh izin menggunakan senjata dari proses peminjaman di gudang senjata oleh petugas gudang. Proses peminjaman senjata pada sebuah gudang masih menggunakan pencatatan manual sehingga membutuhkan waktu. Oleh karena itu perlu adanya sistem untuk mempercepat proses transaksi peminjaman dan pengembalian tersebut ke gudang senjata.

Implementasi aplikasi sistem gudang senjata memanfaatkan framework CodeIgniter, PHP, JavaScript dan barcode. Hasil berupa sebuah aplikasi sistem gudang senjata yang dapat menangani proses transaksi peminjaman dan pengembalian senjata menggunakan barcode. Aplikasi juga dapat mengelola data senjata maupun anggota yang terlibat di dalamnya.
\end{abstract}

Kata kunci: Aplikasi, Gudang, Senjata, Barcode, Javascript, CodeIgniter.

\section{ABSTRACT}

The armory is an important place in a battalion. The function of armoury is weapon place when the weapon is not used by members. Members acquire weapons of the lending process in the armory by armory staff. The process of borrowing in an armory still use manual recording so it takes time. So the armory need a system to speed up the transaction process of borrowing and the returning weapons to the armory.

The implementation of application is using codeigniter framework, PHP, Javascript and barcode. Results of the application armory system that can handle the transaction process of borrowing and returning weapons using barcode. The application also able weapons data management as well as members involved in it.

Keywords: Applications, Armoury, Barcode, Javascript, CodeIgniter

\section{PENDAHULUAN}

Gudang senjata merupakan tempat penting dalam suatu batalyon militer. Di dalam gudang senjata terdapat transaksi peminjaman dan pengembalian senjata oleh anggota sesuai prosedur yang telah disepakati. Proses pencatatan transaksi peminjaman dan pengembalian senjata selama ini masih 
menggunakan cara manual, yaitu dengan mencatat setiap transaksi ke dalam logbook sehingga memerlukan waktu dalam setiap transaksi dan potensi besar bahwa data tidak ter-update.

Penggunaan sistem secara manual telah mengharuskan petugas menghafal setiap senjata milik anggota dan juga pemiliknya. Interaksi komandan pun tidak bisa secara langsung memantau kondisi gudang,hanya terbatas melalui laporan peminjaman dan pengembalian senjata.

Seiring berkembangnya teknologi teknologi informasi dan meningkatnya jumlah pengguna internet, perusahaan teknologi informasi mulai beralih menuju aplikasi berbasis web. Perpindahan ini difaktori oleh keuntungan aplikasi web itu sendiri, diantaranya mudah diakses menggunakan aplikasi browser, tidak perlu instalasi yang rumit, tingkat keamanan tinggi dan cepat dalam memproses data.

Pembuatan aplikasi berbasis web menggunakan bahasa pemrograman PHP (Hypertext Preprocessor). Salah satu framework PHP adalah codeigniter yang memiliki keunggulan lebih ringan dan cepat dibandingkan framework lainnya.

Berikut ini adalah beberapa penelitian yang menjadi referensi penulis dalam menyelesaikan makalah ini. Penelitian yang berhubungan dengan topik yang penulis bahas salah satunya adalah "Penerapan RFID (Radio Frequency Identification) Untuk Pengelolaan Gudang Di Kepolisian"[1]. Penelitian tersebut membahas tentang penerapan sistem RFID untuk proses transaksi peminjaman dan pengembalian senjata sehingga dapat mempermudah pencatatan transaksi. Informasi data senjata terdapat pada id tag yang terpasang pada senjata yang dapat digunakan untuk mencari data pemilik dan data informasi yang terkait dengan id tag tersebut. Petugas hanya melakukan pengecekan pada id tag senjata menggunakan RFID reader untuk pencatatan transaksi peminjaman maupun pengembalian senjata.

Selanjutnya adalah "Sistem Informasi Manajemen Peminjaman Senjata Api Pada Kepolisian Resort Kota Palembang" ${ }^{2]}$. Sistem informasi tersebut dipakai untuk memanajemen senjata api yaitu dapat menginput senjata dan amunisi yang terdapat di gudang. Sistem juga dapat mencatat transaksi peminjaman senjata dengan melakukan penginputan data pemohon dan berita acara senjata api yang bersangkutan. Informasi pemohon senjata dapat ditampilkan dalam laporan daftar pemohon senjata.

Berdasarkan uraian di atas penulis memberikan solusi untuk permasalahan sistem gudang senjata yang masih manual adalah dengan aplikasi sistem gudang senjata berbasis web menggunakan framework codeigniter.

\section{METODOLOGI PENELITIAN}

Metode penelitian yang digunakan untuk menyelesaikan penelitian ini adalah prototyping models. ${ }^{[3]}$. Alur yang dilakukan adalah seperti gambar 1 berikut ini :

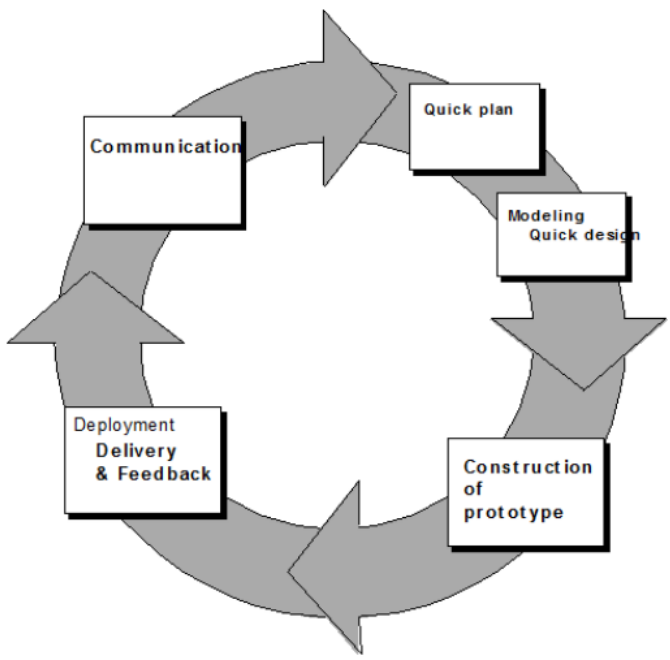

Gambar 1. Prototyping Models 

ini :

Kemudian untuk detail pelaksanaannya dibagai dalam beberapa tahap yakni seperti berikut

\subsection{Wawancara}

Metode pengumpulan data dengan cara bertanya langsung kepada responden yang dilakukan secara sistematis dan berlandaskan kepada tujuan penelitian.

\subsection{Studi Pustaka}

Studi pustaka adalah metode pengumpulan data dengan membaca buku atau literatur literatur yang berhubungan dengan permasalahan yang dijadikan objek dalam penelitian.

2.3. Pengumpulan kebutuhan

Client dan penulis melakukan interaksi mendefinisikan format seluruh perangkat lunak, mengidentifikasikan semua kebutuhan dan garis besar aplikasi yang akan dibuat.

\subsection{Membangun prototyping}

Membangun prototyping dengan membuat perancangan sementara yang berfokus pada bentuk tampilan user interface berformat .html yang nantinya akan diimplementasikan pada sistem.

\subsection{Evaluasi prototyping}

Evaluasi dilakukan oleh client apakah prototyping sudah sesuai dengan keinginan client. Apabila sudah sesuai lanjut untuk pengkodean aplikasi, apabila tidak prototyping akan direvisi.

\subsection{Pengkodean Sistem}

Prototype yang sudah disepakati diterjemahkan dalam bentuk bahasa pemrograman yang sesuai, disini aplikasi menggunakan bahasa PHP.

\subsection{Menguji Sistem}

Pengujian dilakukan setelah aplikasi sudah siap dipakai. Pengujian menggunakan blackbox.

\subsection{Evaluasi Sistem}

Client dan penulis melakukan evaluasi apakah sistem yang dibangun sudah sesuai yang diharapkan. Jika ya maka sistem siap digunakan. Jika tidak maka direvisi lagi.

\section{HASIL DAN PEMBAHASAN}

\subsection{Proses Bisnis Aplikasi}

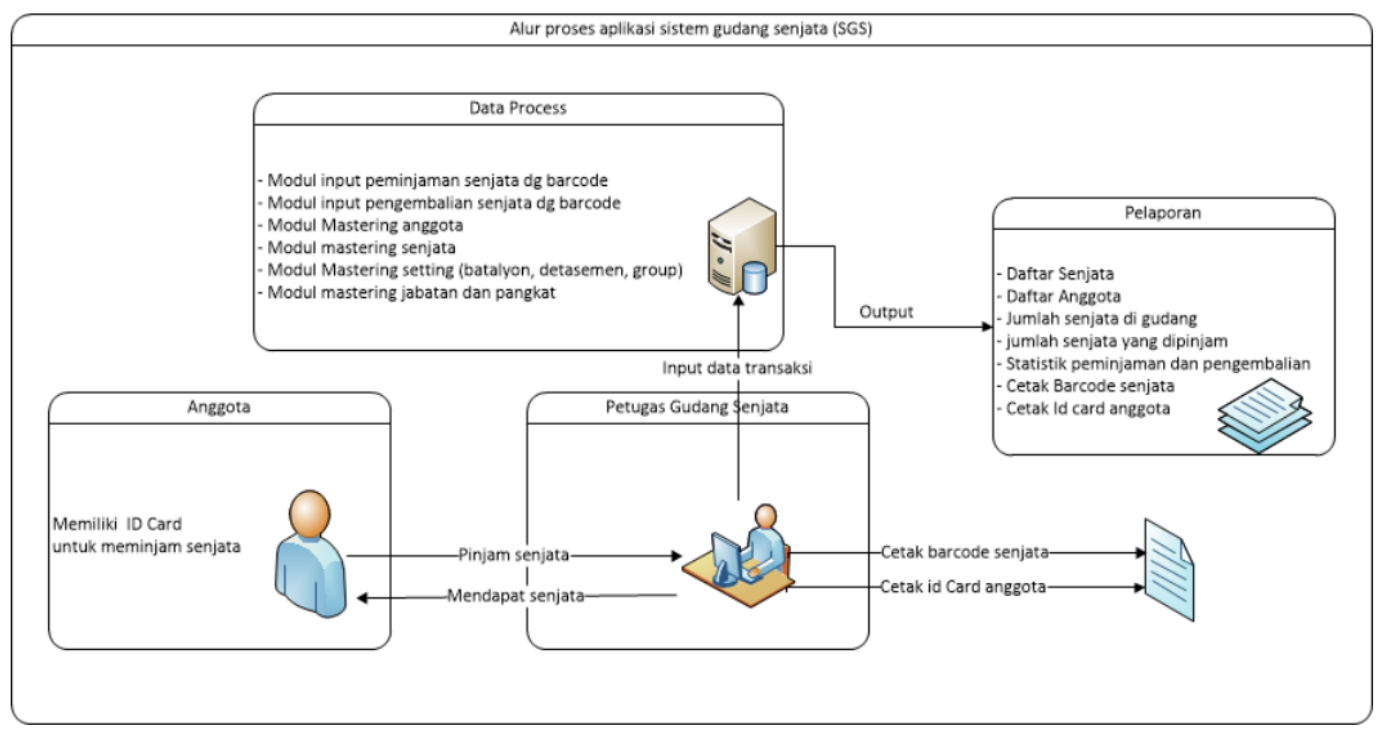

Gambar.2 Alur Proses Bisnis Aplikasi 
Berdasar gambar 2 dijelaksan bahwa fokusnya adalah proses transaksi peminjaman dan pengembalian senjata namun agar anggota dapat melakukan transaksi perlu beberapa hal yang harus dipenuhi. Pertama user dengan hak akses kasi harus menginput data senjata dan anggota ke dalam sistem. Kasi kemudian mencetak barcode senjata dan dilekatkan ke setiap senjata di gudang. Begitu pula dengan id card anggota dicetak dan diserahkan kepada anggota yang terdaftar di sistem.

Petugas gudang adalah user yang memiliki hak akses mengatur transaksi keluar masuk senjata di gudang. Alur peminjaman senjata adalah sebagai berikut, anggota menyerahkan id card anggota kepada petugas gudang. Petugas lalu melakukan scan id card. Data dari id card akan ditampilkan di form sehingga menunjukkan senjata kepemilikan anggota. Petugas lalu mengambilkan senjata dan melakukan scan barcode pada senjata. Anggota akhirnya menerima senjata dengan kesepakatan id card anggota diserahkan ke petugas gudang. Begitu pula utuk proses pengembalian senjata, anggota menyerahkan senjata lalu barcode di scan petugas. Id card anggota yang diserahkan di gudang juga di scan, dengan demikian transaksi tercatat oleh sistem.

\subsection{Use Case}

Pada use case diagram gambar 3 terdapat 4 aktor. Aktor tersebut adalah admin, kasi, gudang dan komandan. Semua aktor yang terlibat adalah user yang sudah login ke dalam aplikasi.

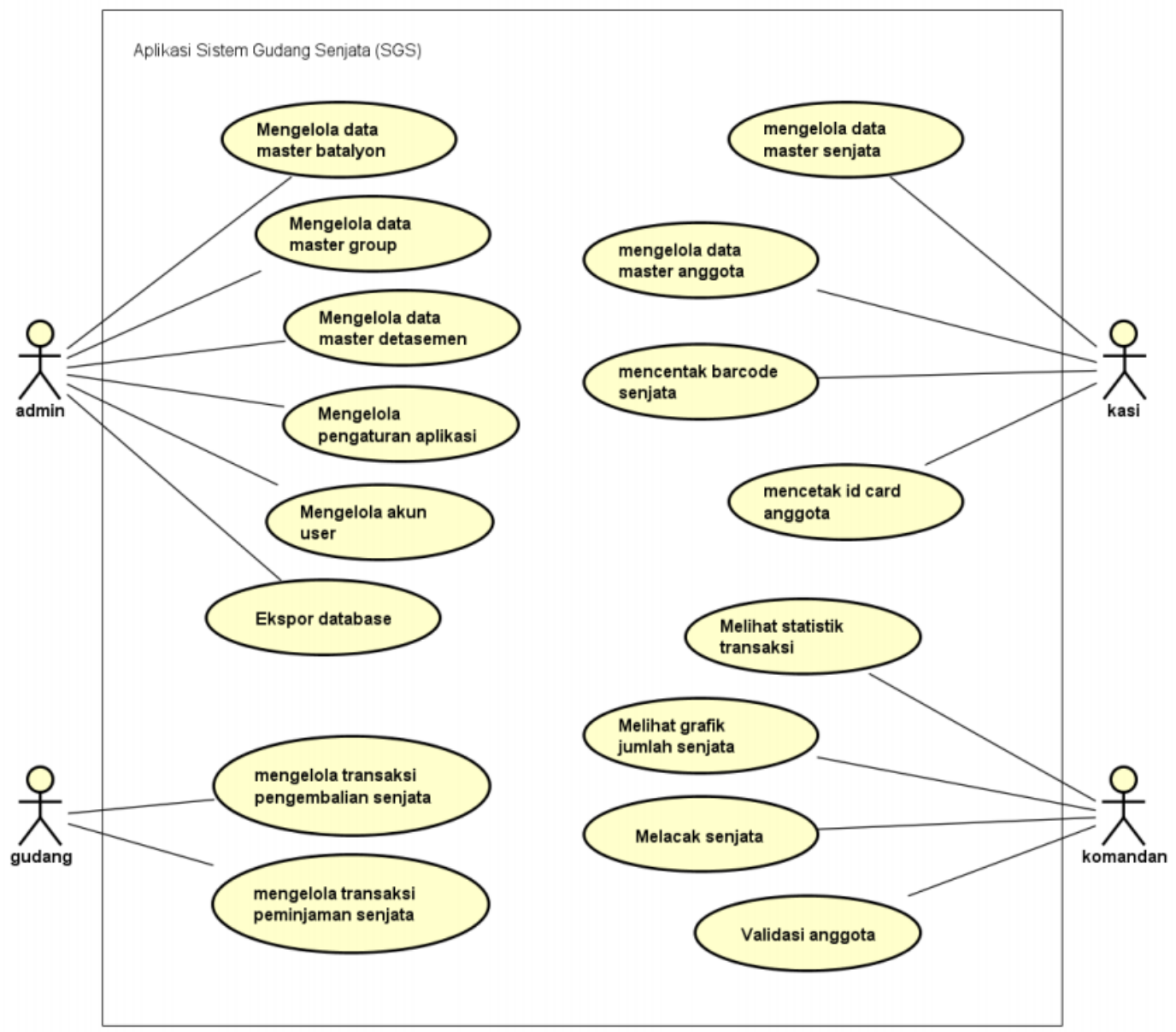

Gambar.3 Use Case Aplikasi SGS

\subsection{ERD}


Dari proses identifikasi aktor dalam use case, maka bisa dibuatlah ERD (Entity Relationship Diagram ${ }^{[4]}$. Seperti yang terlihat dalam gambar 4.

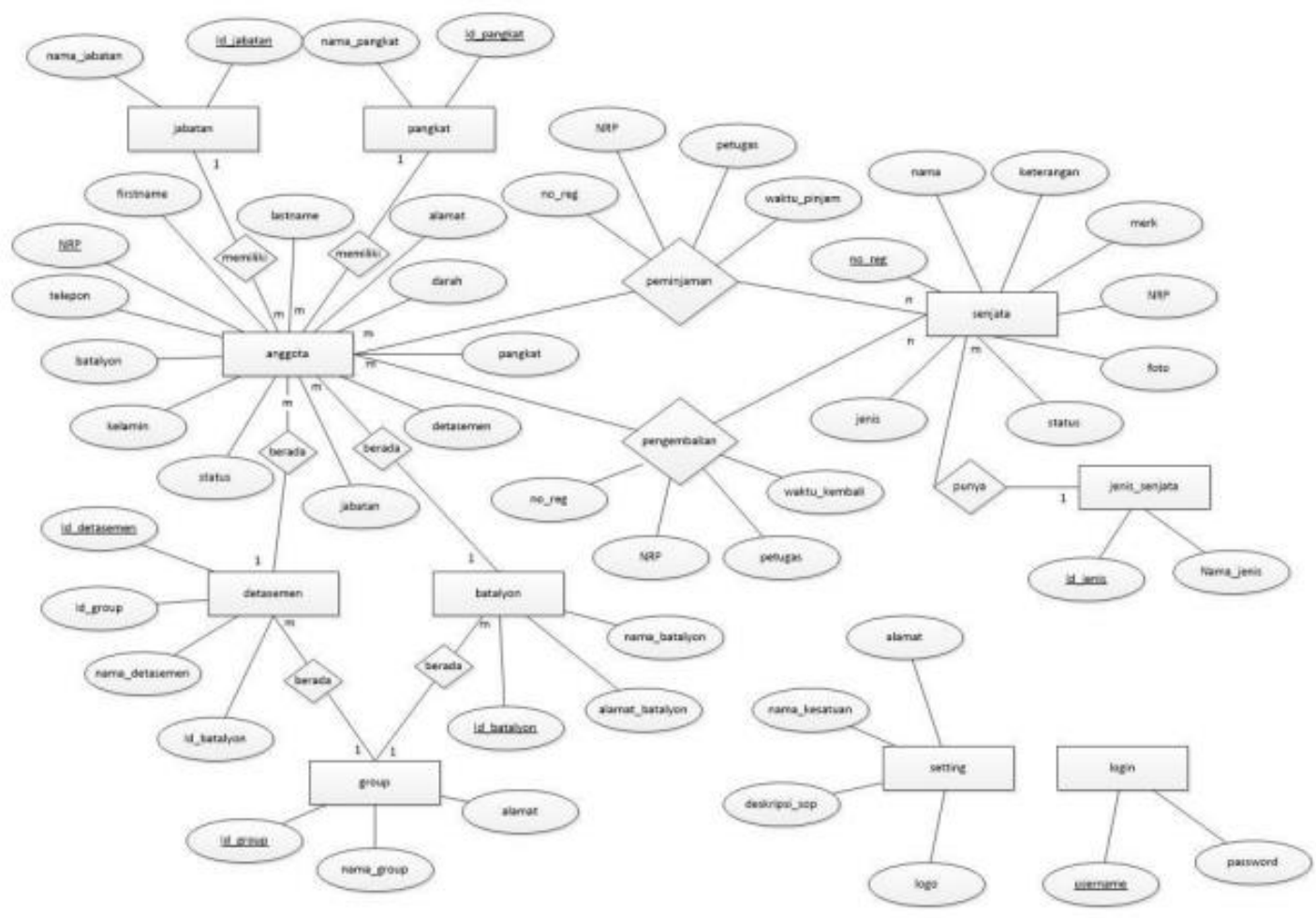

Gambar.4 ERD

\subsection{Relasi Tabel}

Relasi antar tabel menjelaskan hubungan tabel satu dengan tabel yang lainnya apakah one to one, one to many, atau many to many ${ }^{[5]}$. Relasi tabel aplikasi ini dapat dilihat pada gambar 5 .

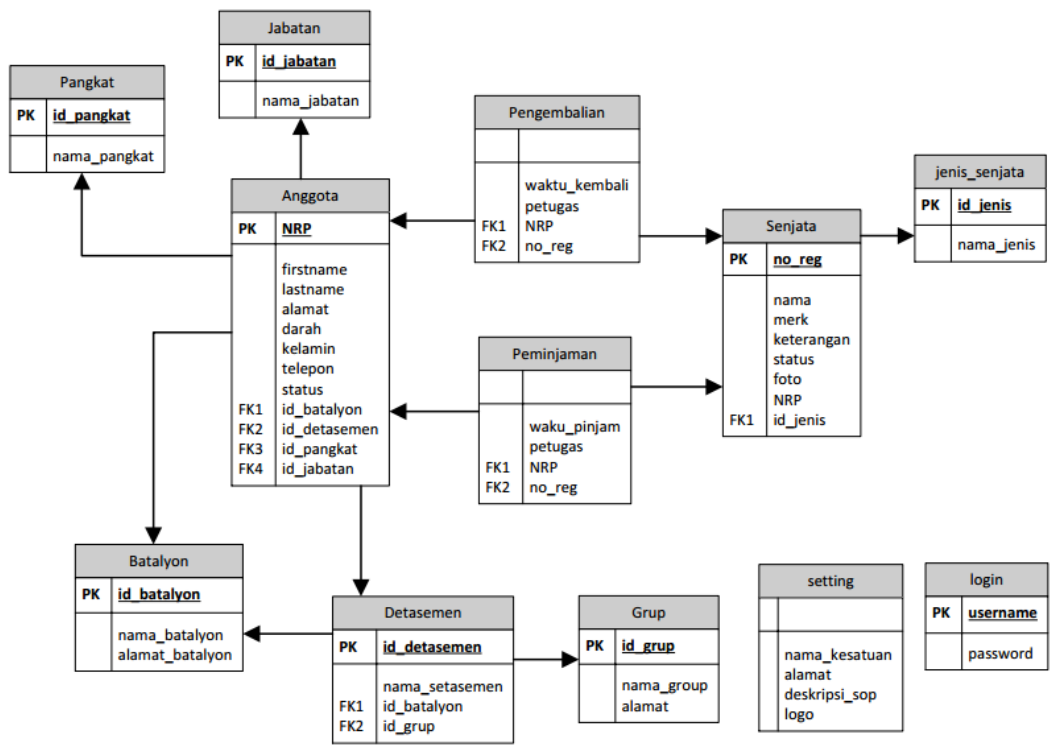


Gambar.5 Relasi Tabel SGS

\subsection{User Interface}

Perancangan desain user interface aplikasi sistem gudang senjata dibedakan menjadi empat bagian utama sesuai dengan level user yakni admin, kasi, gudang dan komandan. Beberapa desain dapat dilihat dalam gambar 6 dan gambar 7, seperti dibawah ini.

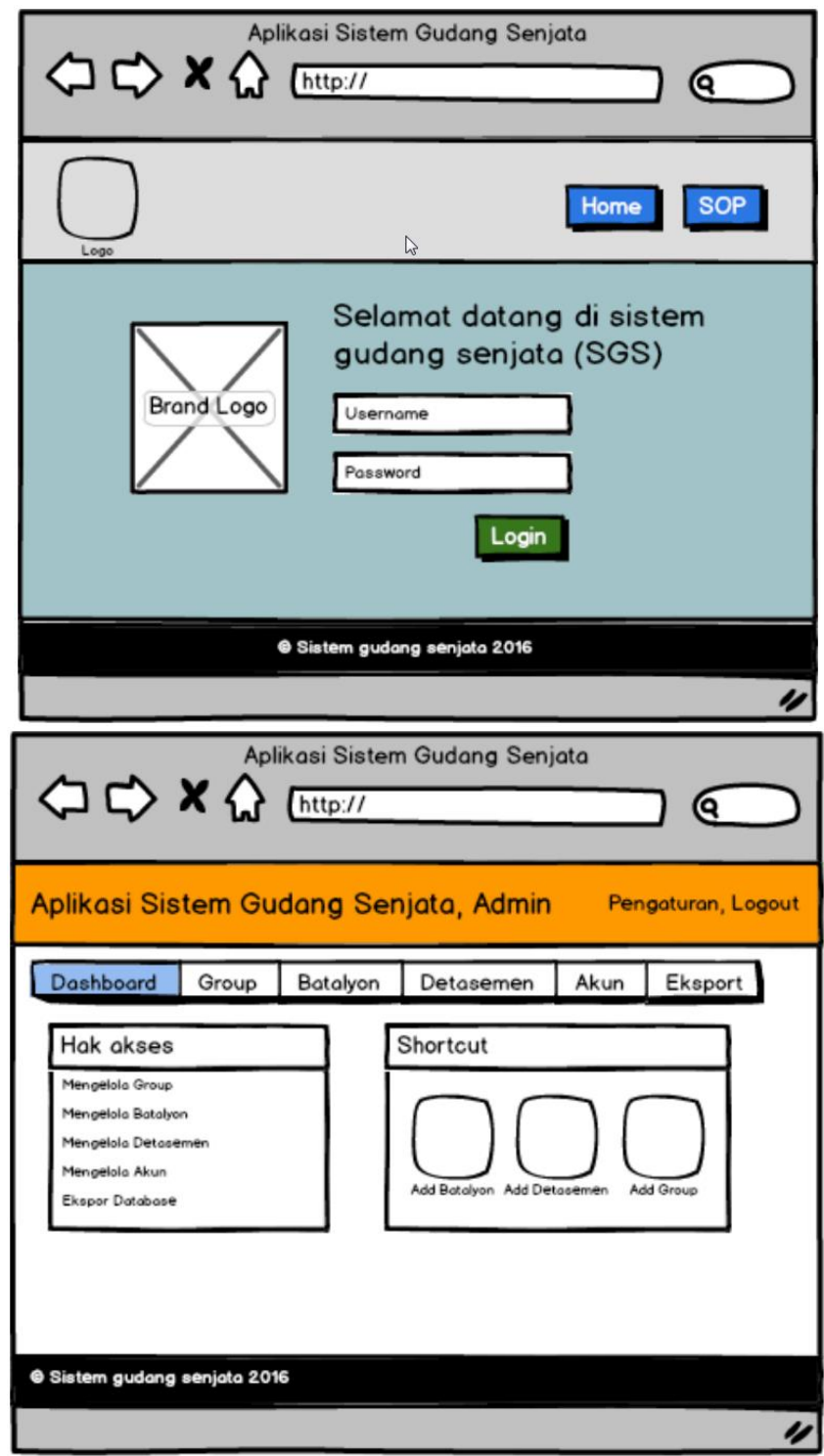

Gambar.6. Halaman Login dan dashboard 


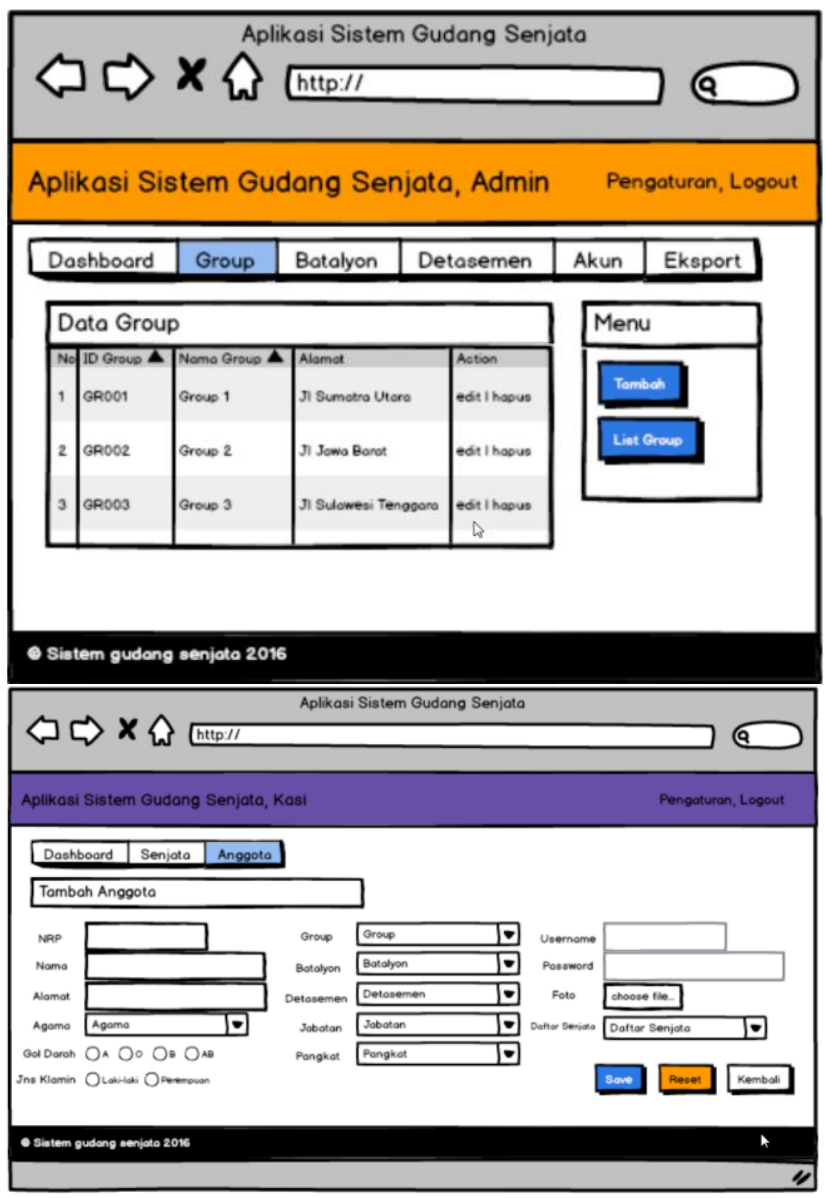

Gambar.7. Halaman tabel dan form master SGS

Sedangkan implementasi rancangan desain dapat dilihat pada gambar 8, 9, 10 dan 11 :

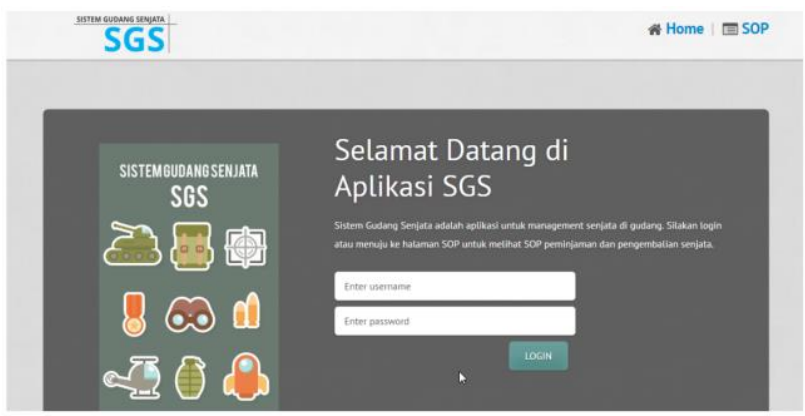

Gambar.8. Halaman Login 
Indonesian Journal of Applied Informatics, Vol. 1 No. 1 November 2016

ISSN: 2548-3846

IIIII Sistem Gudang Senjata, Kasi

$\underset{\text { Dashboard }}{\text { Senjata }_{\text {Anggota }}}$

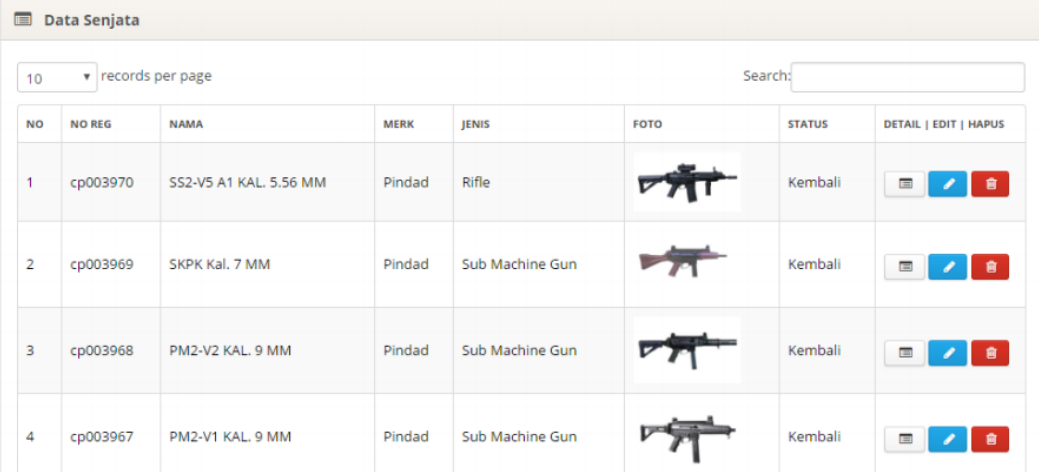

Gambar.9. Halaman Master Senjata
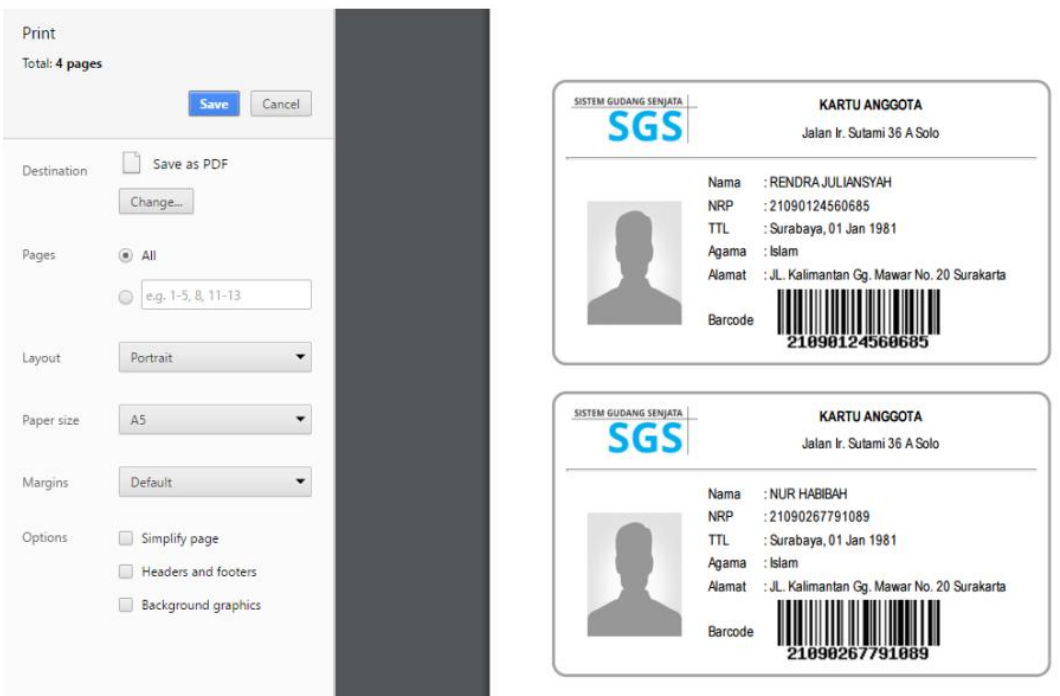

$\square$ Menu

Gambar.10. Halaman Cetak Kartu Anggota 


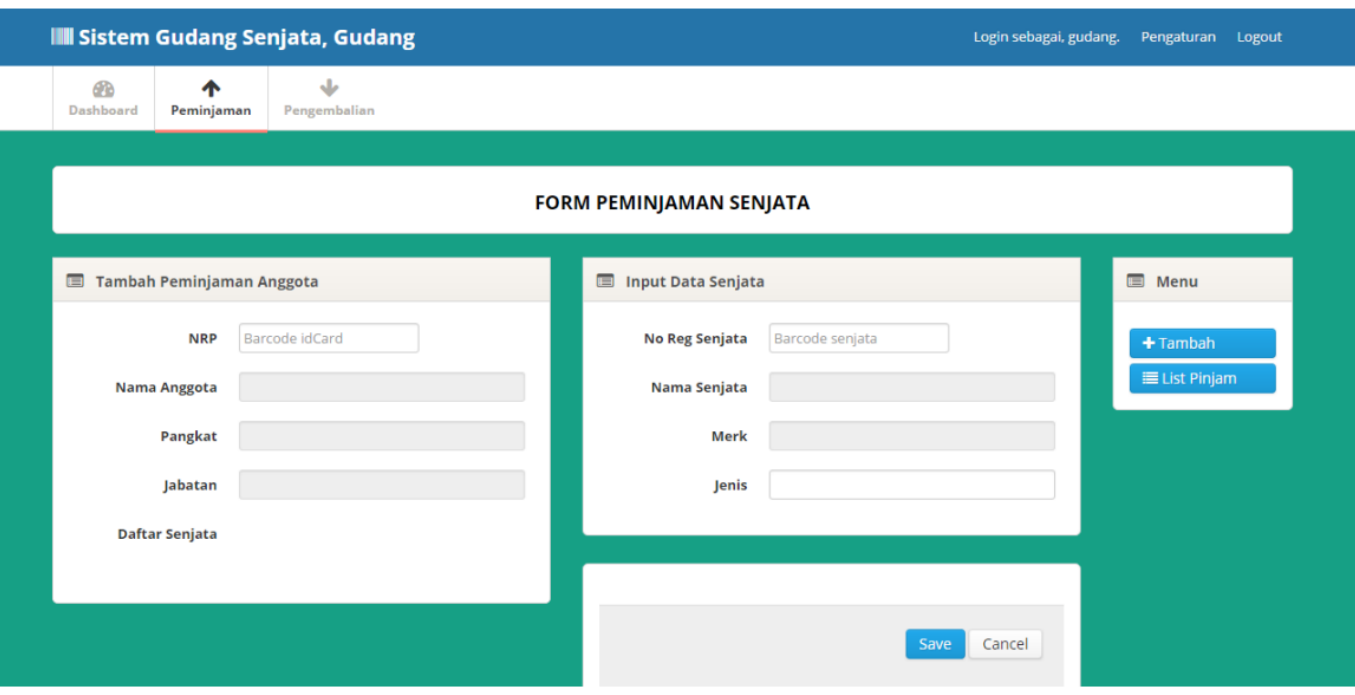

Gambar.11. Halaman Master Senjata

\subsection{Pengujian}

Pengujian sistem dilakukan dengan metode blackbox testing yaitu pengujian yang dilakukan dari segi spesifikasi fungsional tanpa menguji desain kode program ${ }^{[6]}$. Berikut ini adalah beberapa pengujian dari 39 task pengujian seperti pada gambar 12 dan 13 dibawah ini.

\begin{tabular}{llllc}
\hline No & \multicolumn{1}{c}{ Skrenario Pengujian } & Hasil yang diharapkan & Hasil Pengujian & Kesimpulan \\
\hline 1 & $\begin{array}{l}\text { Mengosongkan semua field input } \\
\text { pada form login, kemudian } \\
\text { menekan tombol 'Login' }\end{array}$ & $\begin{array}{l}\text { Sistem menolak login dan } \\
\text { menampilkan pesan login } \\
\text { gagal. }\end{array}$ & Sesuai Harapan & [v] Valid \\
\hline 2 & $\begin{array}{l}\text { Mengisi salah satu field input pada } \\
\text { form login kemudian menekan } \\
\text { tombol 'Login' }\end{array}$ & $\begin{array}{l}\text { Sistem menolak login dan } \\
\text { menampilkan login gagal }\end{array}$ & Sesuai Harapan & [v] Valid \\
\hline 3 & $\begin{array}{l}\text { Mengisi field input pada form } \\
\text { login dengan username }\end{array}$ & $\begin{array}{l}\text { Sistem menolak login dan } \\
\text { menampilkan login gagal }\end{array}$ & Sesuai Harapan & [v] Valid \\
\hline \multirow{2}{*}{$\begin{array}{l}\text { Mengisi field username dan } \\
\text { password dengan data yang benar. }\end{array}$} & $\begin{array}{l}\text { Sistem menolak login dan } \\
\text { menampilkan login gaga }\end{array}$ & Sesuai Harapan & [v] Valid \\
\hline 'Level anggota berstatus & $\begin{array}{l}\text { Mengisota' } \\
\text { password dengan data yang benar. }\end{array}$ & $\begin{array}{l}\text { Sistem menerima login dan } \\
\text { menuju halaman sesuai level } \\
\text { akun login. }\end{array}$ & Sesuai Harapan & [v] Valid \\
\hline
\end{tabular}

Gambar.12. Pengujian bagian Halaman Login 
Indonesian Journal of Applied Informatics, Vol. 1 No. 1 November 2016

ISSN: 2548-3846

\begin{tabular}{lllll}
\hline No & \multicolumn{1}{c}{ Skrenario Pengujian } & Hasil yang diharapkan & Hasil Pengujian & Kesimpulan \\
\hline $\begin{array}{l}\text { Pada form tambah senjata } \\
\text { mengosongkan semua field yang } \\
\text { ada dan menekan tombol 'save'. }\end{array}$ & $\begin{array}{l}\text { Sistem menolak proses } \\
\text { input data dan } \\
\text { menampilkan status } \\
\text { field mana harus diisi }\end{array}$ & Sesuai Harapan & [v] Valid \\
\hline \multirow{2}{*}{$\begin{array}{l}\text { Pada form tambah senjata } \\
\text { mengosongkan field no reg. }\end{array}$} & $\begin{array}{l}\text { Sistem menolak proses } \\
\text { input data dan } \\
\text { menampilkan status } \\
\text { field no reg harus diisi }\end{array}$ & Sesuai Harapan & [v] Valid \\
\hline $\begin{array}{l}\text { Pada form tambah senjata } \\
\text { mengupload gambar dengan } \\
\text { ukuran dan resolusi melebihi } \\
\text { ketentuan }\end{array}$ & $\begin{array}{l}\text { Sistem menolak proses } \\
\text { input dan menampilkan } \\
\text { pesan } \text { error } \text { karena file } \\
\text { gambar terlalu besar }\end{array}$ & Sesuai Harapan & [v] Valid \\
\hline $\begin{array}{l}\text { Pada form tambah senjata mengisi } \\
\text { data sesuai ketentuan kemudian } \\
\text { menekan tombol 'save' }\end{array}$ & $\begin{array}{l}\text { Sistem menerima proses } \\
\text { input dan menampilkan } \\
\text { pesan data disimpan }\end{array}$ & Sesuai Harapan & [v] Valid \\
\hline $\begin{array}{l}\text { Pada form edit senjata mengganti } \\
\text { data yang ingin diubah dan } \\
\text { menekan tombol 'save' }\end{array}$ & $\begin{array}{l}\text { Sistem menerima } \\
\text { perubahan data dan } \\
\text { menampilkan pesan data } \\
\text { berhasil diubah }\end{array}$ & Sesuai Harapan & [v] Valid \\
\hline
\end{tabular}

Gambar.13. Pengujian bagian Halaman Master Senjata

\section{KESIMPULAN}

Telah berhasil dirancang dan dibuat aplikasi SGS (Sistem Gudang Senjata) dengan menggunakan PHP dengan framework CodeIgniter. Aplikasi ini juga menggunakan teknologi barcode dengan tujuan mempercepat dan mempermudah penginputan data ketika proses transaksi peminjaman dan pengembalian senjata oleh pemilik dan petugas gudang.

\section{DAFTAR PUSTAKA}

[1] Harits Subhan, Penerapan RFID (Radio Frequency Identification) Untuk Pengelolaan Gudang di Kepolisian, UMS, 2014

[2] Abdul Haris, Sistem Informasi Manajemen Peminjaman Senjata Api pada Kepolisian Kota Palembang, STMIK PasComTech Palembang, 2015

[3] Pressman, R.S. 2010. Software Engineering: a practitioner's approach. New York: McGraw-Hill.

[4] Abdul Kadir. 2009. Pengenalan Sistem Informasi. Yogyakarta: Andi.

[5] Buyens, Jim. 2001. Web Database Development. Jakarta: Elex Media Komputindo.

[6] Black, Rex. 2009. Managing The Testing Process. Washington: Microsoft Press. 